\title{
“Displaced archives": proposing a research agenda
}

\author{
James Lowry ${ }^{1}$
}

Published online: 24 September 2019

(C) The Author(s) 2019

\begin{abstract}
In the opening keynote speech at the Eighth International Conference on the History of Records and Archives (I-CHORA 8) in Melbourne, Australia, the author provided an overview of archival displacement as an historical phenomenon, before concentrating on postcolonial cases and arguing for a fuller global history of the displacement of archives during decolonisation. The talk concluded with some thoughts on future directions for research on displaced archives. Understanding the term "displaced archives" to refer to any records that have been removed from the context of their creation and whose ownership is disputed, this short article elaborates further upon a potential research agenda for displaced archives, which remains an underresearched area in archival studies.
\end{abstract}

Keywords Displaced archives $\cdot$ Research agenda $\cdot$ Migrated archives $\cdot$ Shared archival heritage $\cdot$ Repatriation

\section{Introduction}

At the Eighth International Conference on the History of Records and Archives (I-CHORA 8), I detailed the history of multilateral efforts to define and address archival displacements (Lowry 2017b) and current work under the Displacements and Diasporas project at the Liverpool University Centre for Archive Studies, which is focused on addressing outstanding issues and claims over displaced records and records in diasporas (Lowry 2017a). This article elaborates a research agenda for displaced archives, which remain under-researched in archival studies. It begins with a discussion of the problem of defining displaced archives, which has been problematic enough while the discourse has focused on displacement between nation states, but becomes more complex if, as proposed in this article, the concept is opened out to other configurations of displacement between other kinds of actors. The article then provides an overview of the Displacements and Diasporas research project,

James Lowry

jlowry@liverpool.ac.uk

1 Liverpool University Centre for Archive Studies, Liverpool, UK 
with background to the international work on archival displacement. After setting out three foundational pieces of research that are needed - a bibliography, a survey of extant cases and case studies - the article then turns to the theoretical possibilities in the study of displaced archives, touching on the concept of a critical theory of displaced archives, as well as records continuum theory and post-custodial thinking, materiality and affect, radical empathy, archival imaginaries, genre studies, speech act theory, research in information cultures, rights in records and other theories and methods. The article concludes by suggesting that the study of displaced archives should be broadened methodologically and in terms of the diversity of voices participating in the discourse and that it should focus on the resolution of archival claims.

\section{Defining displaced archives}

Here, "displaced archives" is used to mean any records that have been removed from the context of their creation and where the ownership of the records is disputed. Examples include the Dutch colonial archives removed from Indonesia though now returned (Karabinos 2017), records created by Iraq's now dispersed Jewish community, relocated to the United States during its invasion of Iraq (Montgomery 2017), records created by defunct nation states, such as Yugoslavia, and claimed by successor nations, and, though under-represented in the displaced archives literature, records of Indigenous communities in custody in the institutions of settler colonial states. There are many other examples, each one unique and complex, involving diverse actors, relations and histories. Because of these complexities, there has been no consensus on terminology (Lowry 2017b). Other terms that have been used in relation to this phenomenon have included "migrated archives", "disputed archival claims", "expatriate archives" and "shared archival heritage". Terms and definitions continue to be discussed and contested in the international archival community and in the literature (Lowry 2017b). Any research that looks beyond individual cases of displacement will have to engage with this problem of naming and defining displaced archives in order to demarcate the parameters of the work and provide a vocabulary for multilateral dialogue.

\section{The Displacements and Diasporas project}

It was with the aim of renewing dialogues around archival displacement that the Displacements and Diasporas project began in 2014. Now based at the Liverpool University Centre for Archive Studies, the project seeks to surface archival displacement as a professional issue requiring discussion and concerted intervention. Research into displaced archives has been ongoing in a number of areas, such as Patricia Kennedy Grimsted's work on records removed to Russia by Soviet forces during and following the Second World War (Grimsted 2007). Similarly, bilateral work to repatriate or copy displaced archives has been ongoing, including high profile returns from the Netherlands to Indonesia and Suriname (Fienieg and Blijd 2017). However, multilateral work in the international professional community of 
archivists had ceased with the failure of the ICA's Displaced Archives Working Group, which was established in 2009 but met only twice and did not begin work on its agenda. This spurred the creation of the Displacements and Diasporas project, which has led to Displaced Archives, an edited book of essays with the stated aim of reviving international discussions on this topic (Lowry 2017a). Ahead of the publication of Displaced Archives, contributors to the book presented a panel at the 2016 Congress of the ICA. At the conclusion of the panel, the President of the ICA announced the formation of the Expert Group on Shared Archival Heritage (EGSAH), led by Njörður Sigurðsson of the National Archives of Iceland, a country with some experience of disputed and repatriated cultural heritage, having received manuscripts from Denmark in an amicable repatriation in 1997. The work of the Displacements and Diasporas project also prompted the Association of Commonwealth Archivists and Records Managers (ACARM) to adopt a position paper calling for the repatriation of the Migrated Archive, a series of records held in Britain but comprising papers removed from 37 former colonies (ACARM 2017). At the ICA's 2018 conference in Yaounde, Cameroon, the President of the Forum of National Archivists (FAN) hosted a discussion about displaced archives, and at the same conference, the EGSAH presented a panel that included presentations on cases including South Africa and Namibia and the Netherlands and Suriname. The panel prompted vigorous debate about some of the ongoing cases and some of the technical problems connected with the resolution of claims, such as definitions of provenance and the physical conditions necessary for safeguarding fragile material. In March 2019, an important development occurred at a meeting of Caribbean archivists in Suriname, where archival repatriation was connected with slavery reparations through the concept of historical justice. Currently, A Proposal for Action on African Archives in Europe (Mnjama and Lowry 2017) is being translated into French, the EGSAH is planning a special issue of Comma, the ICA's journal, and a second volume of Displaced Archives is being prepared.

\section{Foundational research needs}

While all of this incipient work is promising, there is still insufficient contextual information to provide a broad overview of the phenomenon of displaced archives. This would require at least three things. Firstly, an overview of the literature is needed. A fundamental piece of research would be the compilation of a full, multilingual bibliography on the topic. This was proposed as one of the first pieces of work for the ICA's Displaced Archives Working Group, and it is on the agenda for the EGSAH. It is important that the bibliography should be multilingual, since archival displacements span numerous countries, cultures and languages. Taking post-colonial cases alone, there is relatively little available in English about claims over records held in France's Archives Nationales d'Outre-Mer or Spain's Archivo General de Indias, and much of the English literature is inaccessible to people working in other languages. This problem of knowledge siloed by language barriers can be seen across archival studies, and there is a general need for much more translation and international, intercultural 
sharing. This is amongst the aims of the recently established International Intellectual History of Archival Studies (IIHAS) research network (nd).

Secondly, information about extant cases would help to form a picture of the causes and extent of the problem. In 1998, UNESCO published the results of Leopold Auer's international survey on disputed archival claims (Auer 1998). Auer, working within the nation state-oriented framework of the ICA, circulated a first questionnaire to the national archives of 83 countries. Forty-five did not respond at all; eight national archives did not wish to participate; and one preferred a bilateral contact. The archives of five countries reported no disputed archival claims. The remaining 24 national archives responded positively to the first questionnaire, identifying 61 disputed archival claims against 25 countries. They were sent a second, more detailed questionnaire. The 17 responses to the second questionnaire provided detail on the claims, though Auer notes some discrepancies in the data across the two surveys. Currently, under the Displacements and Diasporas project, the Liverpool University Centre for Archive Studies is repeating this survey on behalf of the EGSAH, to form an updated picture of outstanding archival claims. The survey closed in January 2019, and the results are currently being analysed.

The data from this survey are bound to be incomplete, as was the first dataset, because participants were self-selecting. It is possible that the results of this survey will show that cases reported by Auer have been resolved or remain open, but there is unlikely to be directly comparable data on all cases: the international political situation has changed since the first survey, and those who reported claims in the 1990s may be unable or unwilling to report claims now, and vice versa. Furthermore, the literature shows that new displacements have occurred and old claims have been resolved, but these cases may not have been reported through the current survey. The results of the current survey are also likely to present more diverse configurations of actors than were apparent in Auer's data, since the wording in the new data collection instrument varies from the original, encouraging reporting on cases beyond the nation state, such as cases involving communities, non-government organisations, First Nations, religious organisations and the private sector. Furthermore, the recent survey was open to all, rather than directed at national archives. The data will be incomplete and not directly comparable with the first dataset, but even this partial data could provide insights into the general phenomenon since a preliminary look at the data shows circumstances and cases that are not yet analysed in the literature.

Thirdly, individual and comparative case studies and other investigations into the history of the phenomenon would allow for longitudinal studies and might provide insights into how disputes have been settled or partly settled, or the factors that have contributed to their continuation. Such historical analyses would be aided by the completed bibliography and survey. Again, all of these lines of work would need to grapple with terminology and definitions.

Beyond this fundamental research, there are many directions that research could take. 


\section{Theoretical approaches to the study of displaced archives}

In "Radical Empathy, The Imaginary and Affect in (Post)Colonial Records: How to Break Out of International Stalemates on Displaced Archives" (Lowry 2019), I applied concepts recently introduced into archival theory by Michelle Caswell, Anne Gilliland and Marika Cifor (Caswell 2014; Caswell and Gilliland 2015; Cifor 2016; Cifor and Gilliland 2016; Gilliland and Caswell 2016) to Kenyan papers held in Britain. My study found that the concepts, which are epistemologically far removed from the rights-based thinking that informs orthodox archival theory, nevertheless reaffirm the need for repatriation in that particular case. However, these concepts offer a radically new perspective on the ethics of custodianship and challenge individual archivists to take responsibility, rather than directing (and diffusing) responsibility at the institutional level. Much more could be done with these concepts, taken separately. For instance, autoethnographic studies of affective engagements with displaced records could give a fuller picture of the significance of these records for those individuals and communities documented in displaced archives. However, I also argue for the integration of these and other relevant concepts into a "critical displaced archives theory". This notion builds on the emergence of "critical archival studies", defined by Caswell et al. (2017) as "those approaches that (1) explain what is unjust with the current state of archival research and practice, (2) posit practical goals for how such research and practice can and should change, and/or (3) provide the norms for such critique" (p. 2). "A critical theory for displaced archives would be critical in its aim to explain injustices in cases of archival displacement, posit practical goals for their resolution, and provide a set of norms for achieving those aimspreliminarily affect, the imaginary and radical empathy" (Lowry 2019, p. 198). Importantly, such a theory, if it is to be developed, must develop through open collaboration across economic, cultural and national boundaries if it is to make a contribution to and reflect the precepts of critical archival studies.

As observed in Displaced Archives (2017), the records continuum theory, developed by Australian archival theorists from the 1990s onwards (McKemmish et al. 2010), has only started to inform work in this area, as evidenced, for example, by the work of Lovering (2017), Karabinos $(2015,2017)$ and Gilliland (2017). Lovering evokes the continuum in his description of the Rhodesian army records that were created in a colonial nation now reconstituted as an independent country, by a group of people now in diaspora. These records were annexed to South African archives and finally transported to the UK where they now exist in a legal limbo. Karabinos (2017) posited that the Dutch military seizure of Indonesian records constituted those records as a new archive, an idea also explored in his doctoral thesis (2015). A recent article by Frings-Hessami (2019) responds to Karabinos' use of the continuum in the context of displacement, and to his conceptualisation of a "shadow continuum", though her primary focus is the robustness of the continuum model, rather than the value of continuum perspectives for resolving archival claims. A study of displaced archives that is fully positioned within a continuum perspective and engages deeply with the theory 
could radically reshape how archival displacement is conceived. Relatedly, postcustodial thinking has not been fully factored into the displacement discourse, though Gilliland's (2017) introduction of the concept of post-nationalism opened that line of enquiry, asking what it means to reify the notion of the nation state in an increasingly globalised world. What about the records that are currently and will in the future be created using networked technology, the cloud or social media that do not recognise national borders? From a post-custodial perspective, place and belonging in the digital environment, regimes for data sovereignty and the technologies of information transmission all become relevant to the study of archival displacement.

Our understanding of displaced archives could also be enriched by work on materiality, in connection with questions such as

What value does the data have, and what value the records?... When what constitutes the original is unclear, does, or could, or should that change the perception of the adequacy of copies in settling disputes? ... Could new thinking about materiality and affect in archives reinforce the symbolic power of the originals, as artefacts of unique and significant value? (Lowry 2017 p. 9)

Vismann's (2008) concept of the file as a material manifestation of official power, especially in studies of post-colonial and post-conflict cases of archival displacement, might surface the importance of displaced records as actively and persistently enacting geopolitical power imbalances and abuses. Palacios' (2015) papers as actors in material networks and Bennett's (2010) political ecology of things could be used to examine displaced archives for what they do and do not do in each of their possible contexts and locations. Dworkin's (2013) study of blank media and Henri Lefebvre's catalogue of missing and unrealised cultural artefacts (2014) could help us think about the absence and its implications for archives and their subjects and users. The work on digital materiality (Rimmer et al. 2008; Leonardi 2010; Dever 2013; Rekrut 2014) is potentially enormously helpful in thinking through the viability of settling archival claims through digitisation. Archival studies scholars could use materiality to rethink displaced archives in significant ways.

There are numerous other theoretical possibilities. The application of genre studies in archives (Oliver and Duff 2012; Foscarini 2015; MacNeil 2015; Foscarini and Ilerbaig 2017), Geoffrey Yeo's (2010, 2017) work on speech act theory, Oliver and Foscarini's (2014) work on information culture, the "rights in records" concept at the heart of the Refugee Rights in Records (UCLA Center for Information as Evidence 2018) and Setting the Record Straight for the Rights of the Child (Setting the Record Straight for the Rights of the Child Initiative 2017) projects, the new models proposed in Archives in Liquid Times (Smit et al. 2017) and any of the methods and concepts put forward in Research in the Archival Multiverse (Gilliland et al. 2016) might illuminate archival displacement and, in return, their applications to archival displacement might enrich or extend the concepts and tools being developed or introduced into archival studies. These interventions could stand alone or, as suggested previously (Lowry 2019), they could contribute to a new critical theory of displaced archives. 


\section{Broadening the discourse around displaced archives}

There is also likely to be work in related fields that would be useful for the study of displaced archives. There may be parallels with disputes over artefacts, human remains or books in museum studies, archaeology and librarianship, for instance. Some of the work in those fields is already discussing archives (van Beurden 2017). There is also a need for much more research into displacement between other actors, such as sub-national governments, First Nations, non-government organisations, religious organisations, the private sector and private collections. The preliminary data from the recent EGSAH survey suggest that the issue is much more complex than previously acknowledged in multilateral work at the level of the nation state. There is also a need to relate this archival problem to broader social, cultural and geopolitical issues. At I-CHORA 8, I suggested a connection between the stories in and about a series of displaced archives held in Britain, known as the Migrated Archive, and colonial nostalgia in the culture industry, citing the whitewashed portrayal of British colonialism in recent films and the 2014 YouGov survey that found 59\% of British people believe that the British Empire was something to be proud of (Dahlgreen 2014). The records in the Migrated Archive and the story of the archive itself cast a different light on British imperialism - the collection was "discovered" after four Kenyans brought an ultimately successful claim against the British government for atrocities suffered during Kenya's independence struggle-and this difference warrants a closer reading. The same archive could also be examined in terms of foreign policy, cultural diplomacy or political ideology. There is, then, an array of disciplines, subjects and framings that could be brought together to study archival displacement's history and ongoing repercussions.

Importantly, any studies should consider how they contribute to the resolution of disputed claims. Research outputs might usefully go beyond scholarly publications. The EGSAH survey results will be written up, but the survey's primary purpose is to inform the group's work plan. The Displacements and Diasporas project has prompted ACARM to adopt a position paper, and it is working towards engagement with British parliamentarians on the fate of the Migrated Archive. How could further research be channelled into policy formation, dialogue creation and professional mobilisation?

A general observation about the research to date is that the writing about this subject is dominated by the Global North. The introduction to Displaced Archives (Lowry 2017a, b) noted the lack of diversity amongst the contributors to that book. This can partly be attributed to the fact that archivists in the Global South who are concerned with this issue are usually government employees who are unable for political and diplomatic reasons to put their concerns in writing. The voices in this conversation have become more diverse over the last 2 years, with new work soon to be published about the repatriations to Suriname and Namibia, for example. One objective of the work around displaced archives needs to be making more space and providing more platforms for the voices of those most affected by archival displacement, who are typically those in countries or 
communities from which records have been removed, often mirroring geopolitical and economic asymmetries of power. It is this connection between archival displacement and power that makes research into and action on displaced archives imperative, but that action needs to be equitable too.

\section{Conclusion}

There is a rich vein of work in the study and resolution of archival displacement. Each case is a unique assemblage of factors that often include complex histories, laws or legal regimes, socio-economic and geopolitical elements and archival problems, both theoretical and technical. Diverse tactics and perspectives are needed if the issues are to be untangled and resolutions are to be found. There is work here for practicing archivists, archival studies scholars, historians, jurists and technologists, amongst others. There is scope for useful work across disciplines and across cultures, sectors and countries. This article has identified some of the trajectories that work might take. Its objective has been to encourage participation in the work of understanding and resolving disputes over displaced archives. Such studies are not merely academic exercises: historical and current imbalances of power are reflected in many cases of archival displacement, so there is a clear ethical impetus for the work that remains to be done.

Open Access This article is distributed under the terms of the Creative Commons Attribution 4.0 International License (http://creativecommons.org/licenses/by/4.0/), which permits unrestricted use, distribution, and reproduction in any medium, provided you give appropriate credit to the original author(s) and the source, provide a link to the Creative Commons license, and indicate if changes were made.

\section{References}

ACARM (2017) The migrated archives: ACARM position paper, adopted by unanimous vote at the ACARM annual general meeting, Mexico City, 25 November 2017

Auer L (1998) Disputed archival claims. Analysis of an international survey: a RAMP study. http://unesd oc.unesco.org/images/0011/001134/113472eo.pdf. Accessed 20 Dec 2018

Bennett J (2010) Vibrant matter: a political ecology of things. Duke University Press, Durham

Caswell M (2014) Toward a survivor-centered approach to records documenting human rights abuse: lessons from community archives. Arch Sci 14(3-4):307-322

Caswell M, Gilliland A (2015) False promise and new hope: dead perpetrators, imagined documents, and emergent archival evidence. Int J Hum Rights 19(5):615-627

Caswell M, Punzalan R, Sangwand T (2017) Critical archival studies: an introduction. J Crit Libr Inf Stud 1:2. https://doi.org/10.24242/jclis.v1i2.50

Cifor M (2016) Affecting relations: introducing affect theory to archival discourse. Arch Sci 16(1):7-31

Cifor M, Gilliland A (2016) Affect and the archive, archives and their affects: an introduction to the special issue. Arch Sci 16(1):1-6

Dahlgreen W (2014) The British Empire is 'something to be proud of'. https://yougov.co.uk/topics/polit ics/articles-reports/2014/07/26/britain-proud-its-empire. Accessed 20 Dec 2018

Dever M (2013) Provocations on the pleasures of archived paper. Arch Manuscr 41(3):173-182

Dworkin C (2013) No medium. MIT Press, Cambridge

Fienieg A, Blijd S (2017) Paper memory of suriname returns home. https://dutchculture.nl/nl/news/surin ame-paper-memory-suriname-returns-home. Accessed 23 Jan 2019 
Foscarini F (2015) Organizational records as genres: an analysis of the "documentary reality" of organizations from the perspectives of diplomatics, records management, and rhetorical genre studies. In: Andersen $\mathbf{J}$ (ed) Genre theory in information studies (studies in information, volume 11). Emerald Group Publishing Limited, Bingley, pp 115-132

Foscarini F, Ilerbaig J (2017) Intertextuality in the archives. In: Smit F, Glaudemans A, Jonker R (eds) Archives in liquid times. Stichting Archiefpublicaties, 's-Gravenhage, pp 176-194

Frings-Hessami V (2019) The flexibility of the records continuum model: a response to Michael Karabinos' "in the shadow of the continuum". Arch Sci. https://doi.org/10.1007/s10502-019-09316-w

Gilliland A (2017) Networking records in their diaspora: a reconceptualisation of "displaced records" in a postnational world. In: Lowry J (ed) Displaced archives. Routledge, Abingdon, pp 180-195

Gilliland A, Caswell M (2016) Records and their imaginaries: imagining the impossible, making possible the imagined. Arch Sci 16(1):53-75

Gilliland A, McKemmish S, Lau A (2016) Research in the archival multiverse. Monash University Publishing, Clayton

Grimsted PK (2007) Returned from Russia: Nazi Plunder of archives in Western Europe and recent restitution issues. Institute of Art and Law, Leicester

International Council on Archives (n.d.) Expert group on shared archival heritage. https://www.ica.org/ en/expert-group-on-shared-archival-heritage-egsah. Accessed 20 Jan 2019

International Intellectual History of Archival Studies (IIHAS) Research Network (nd) About. https://histo ryofarchivaltheory.home.blog. Accessed 11 Aug 2019

Karabinos M (2015) The shadow continuum: testing the records continuum model through the Djogdja Documenten and the migrated archives. PhD Dissertation, Leiden University

Karabinos M (2017) Indonesian national revolution records in the national archives of the Netherlands. In: Lowry J (ed) Displaced archives. Routledge, Abingdon, pp 60-73

Lefebvre H (2014) The missing pieces. MIT Press, Cambridge

Leonardi PM (2010) Digital materiality? How artifacts without matter, matter. First Monday 15(6-7). https://firstmonday.org/article/view/3036/2567. Accessed 20 Jan 2019

Lovering T (2017) Expatriate archives revisited. In: Lowry J (ed) Displaced archives. Routledge, Abingdon, pp 86-100

Lowry J (ed) (2017a) Displaced archives. Routledge, Abingdon

Lowry J (2017b) Introduction. In: Lowry J (ed) Displaced archives. Routledge, Abingdon, pp 1-11

Lowry J (2019) Radical empathy, the imaginary and affect in (post) colonial records: how to break out of international stalemates on displaced archives. Arch Sci 19:185-203

MacNeil H (2015) The role of calendars in constructing a community of historical workers in the public records office of Great Britain ca. 1850s-1950s. In: Andersen J (ed) Genre theory in information studies (studies in information, volume 11). Emerald Group Publishing Limited, Bingley, pp 91-113

McKemmish S, Upward F, Reed B (2010) Records continuum model. Encyclopedia of library and information sciences, 3rd edn. CRC Press, Boca Raton, pp 4447-4448

Mnjama N, Lowry J (2017) A proposal for action on African archives in Europe. In: Lowry J (ed) Displaced archives. Routledge, Abingdon, pp 101-113

Montgomery B (2017) Iraq and Kuwait: the seizure and destruction of historical patrimony. In: Lowry J (ed) Displaced archives. Routledge, Abingdon, pp 158-179

Oliver G, Duff W (2012) Genre studies and archives: introduction to the special issue. Arch Sci 12(4):373-376

Oliver G, Foscarini F (2014) Records management and information culture: tackling the people problem. Facet Publishing, London

Palacios J (2015) Archival liveness: the paper archive in the digital age. Perform Matters 1(1-2):62-69

Rekrut A (2014) Matters of substance: materiality and meaning in historical records and their digital images. Arch Manuscr 42(3):238-247

Rimmer J et al (2008) An examination of the physical and the digital qualities of humanities research. Inf Process Manag 44(3):1374-1392

Setting the Record Straight for the Rights of the Child Initiative (2017) Setting the Record Straight for the Rights of the Child. https://rights-records.it.monash.edu. Accessed 18 Dec 2018

Smit F, Glaudemans A, Jonker R (2017) Archives in liquid times. Stichting Archiefpublicaties, 's-Gravenhage

UCLA Center for Information as Evidence (2018) Refugee rights in records project. https://informatio nasevidence.org/refugee-rights-in-records. Accessed 18 Dec 2018 
Van Beurden J (2017) Treasures in trusted hands: negotiating the future of colonial cultural objects. Sidestone Press, Leiden

Vismann C (2008) Files: law and media technology. Stanford University Press, Stanford

Yeo G (2010) Representing the act: records and speech act theory. J Soc Arch 31(2):95-117

Yeo G (2017) Information, records, and the philosophy of speech acts. In: Smit F, Glaudemans A, Jonker (eds) Archives in liquid times. Stichting Archiefpublicaties, 's-Gravenhage, pp 92-118

Publisher's Note Springer Nature remains neutral with regard to jurisdictional claims in published maps and institutional affiliations.

James Lowry is co-director of the Liverpool University Centre for Archive Studies. His recent publications include Displaced Archives, an edited collection published by Routledge in 2017, and Integrity in Government through Records Management, which he edited with Justus Wamukoya, published by Ashgate in 2014. James is series editor for Routledge Studies in Archives. 